\title{
Effect of Cement Kiln Dust on the Radiation Balance and Yields of Plants
}

\author{
Angéla Anda \\ Agrometeorological Research Station, \\ 8361 Keszthely Pf. 80, Hungary
}

ABSTRACT

Changes in the radiation balance (albedo) of maize polluted with cement dust were measured at the Agrometeorological Research Station, Keszthely, Hungary, during 1982-84. The radiation intake of polluted plants was increased, and this increased plant temperature and evapotranspiration. Higher radiation values did not have a positive effect on dry matter production; in fact, fertilisation was found to deteriorate and yields on average decreased by $16 \cdot 2 \%$ during the three years.

\section{INTRODUCTION}

The effects of cement dust on plants (especially on fruit setting) were already being studied at the beginning of the twentieth century (Peirce, 1910; Anderson, 1914). Later, the negative effect of cement dust was considered to be the result of several unfavourable factors, with direct effects (dust formation, incrustation, necrosis) and those influencing physiological processes and yields. As a rule, these publications focused on a narrow field of injury, e.g. changes in the accumulation of mineral plant nutrients as a result of cement dust (Lal \& Ambasht, 1982), whereas Darley (1966), Dobreva \& Szlaveva (1974), Borka (1981) and several others studied the $\mathrm{CO}_{2}$ exchange and photosynthesis of polluted plants. Only a few papers, however, have dealt with differences to be found in radiation balance caused by pollution, and the published results were not always clear-cut.

Environ. Pollut. Ser. A. 0143-1471/86/S03.50 (C) Elsevier Applied Science Publishers Ltd, England, 1986. Printed in Great Britain 
Peirce (1910) stated that starch formation on citrus trees decreased as a result of interference to light caused by pollution with cement, which formed a crust on the leaves. According to Steinhübel (1966), the radiation absorbing and reflecting capacity of dust-covered plants changed, although the author did not give the direction of the change. Bohne (1963) stated that the unfavourable effect of cement dust on radiation balance was responsible for the decreased photosynthetic activity in polluted plants. Singh \& Rao (1981) found that the surface of plants polluted with cement dust receives less radiation. This was confirmed by Lal \& Ambasht (1982). Eller (1977), on the other hand, obtained the opposite result concerning radiation in the spectral region of $700 \mathrm{~nm}$; i.e. the radiation absorption of contaminated plants was doubled.

\section{MATERIALS AND METHODS}

Changes in the radiation balance of maize polluted with cement were measured at the Agrometeorological Research Station, Keszthely, during 1982-84. The size of the plot tested was equal to the surface of a circle $10 \mathrm{~m}$ in diameter, since an area of that size was necessary to ensure the reliable and undisturbed operation of the actinometer (i.e. all the instruments used for measuring the intensity of radiation energy arriving from the sun).

The dust used for artificial pollution was collected not far from one of the chimneys of the Cement and Lime Mills of Vác on the Danube; the extent of pollution was identical with the actual deposition of cement dust in normal emission conditions with the rate of pollution measured in $2-10 \mathrm{~km}$ area from the chimney, in the prevailing wind direction. The amount of dust deposited on the plants - and that of the dust applied in the experimental plot - was determined by incinerating the plant samples collected about every 2 weeks from sites around the factory during the experimental period. Dust at a rate of $30 \mathrm{~g} \mathrm{~m}^{-2}$ was applied, being sifted on to the plants by hand every second or third day.

In 1982, radiation was measured using a portable Janisevszkij (M-69) type albedometer. In 1983-84 field measurements were replaced by continuous measurement and registration of total irradiation, on an automatic paper-tape punch, together with a Kipp-type actinometer. This meteorological instrument measures and records the intensity of 

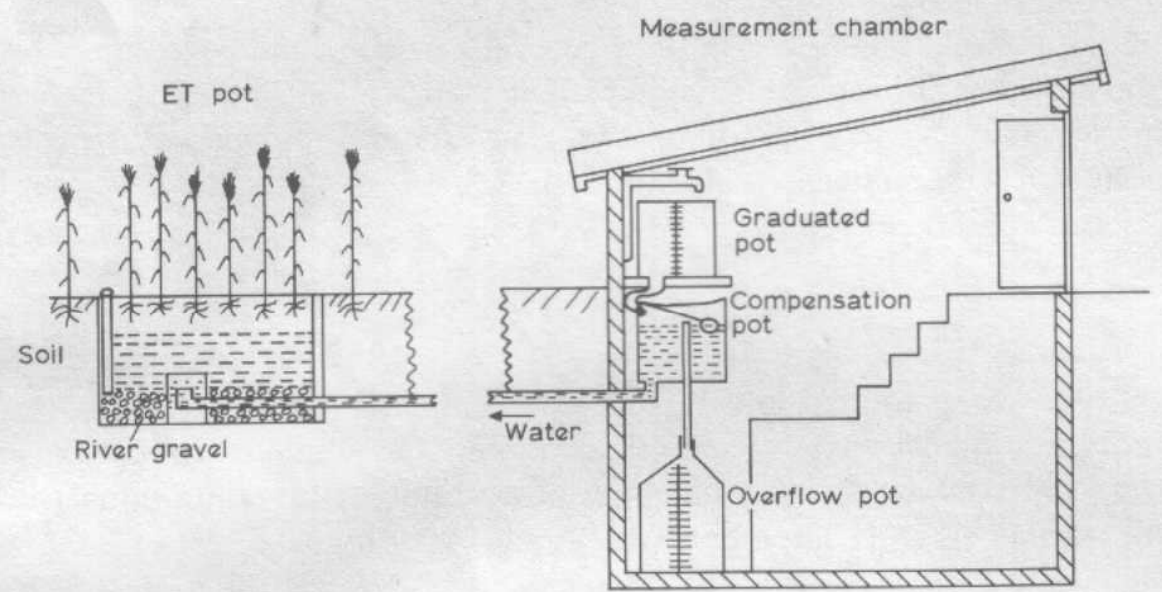

Fig. 1. The Thornthwaite-type compensation evapotranspirometer.

radiation, the amount of energy radiated by the sun per unit time and in a given direction.

Plant temperature was measured on an infra-thermometer of Raynger II RTL type, and evapotranspiration on a Thornthwaite-type compensation evapotranspirometer (Fig. 1). Evapotranspiration values were given in total daily amounts determined by the change in the volume of soil water in the evapotranspirometer, by the additional water supply through the compensation pot and by precipitation values. The instrument records the complete water balance under natural conditions and thus the evapotranspiration of the plant stand can be determined correctly.

The assimilatory surface was measured every week with an automatic hand-held LI-3000 planimeter and the value of the leaf area was assessed by use of the leaf-area index (LAI) in all treatments. At the end of the vegetative period, yields were evaluated, including a fertilisation test.

The sun is the only source of energy which affects almost all the plant physiological processes (transpiration, thermal effects, photosynthesis, photomorphogenetic effect). The crop canopy, following the reflection of the incident rays from the surface, is enriched with the amount of net radiation, including that reflected from the soil surface. The ability of the surface to reflect short-wave radiation can also be expressed as a ratio of total solar irradiation, the quotient obtained being the albedo, $0 \leq a \leq 1$. Consequently, if the crop canopy absorbs incident radiation it is 0 and if it reflects it totally it is 1 . Its value is obviously determined by the geometric 
and optical characteristics and the general condition and development of the crop in addition to the height of the sun.

We characterised the differences in radiation balance caused by pollution with changes in albedo.

\section{RESULTS AND DISCUSSION}

In 1982 we examined albedo only on completely clear days, because radiation intensity was constantly changing and single treatments were not comparable (the instrument was unsuitable for continuous field measurement). Measurements were made every hour between 0700 and

TABLE 1

Daily Means of Albedo on Cloudless Days

\begin{tabular}{lcc}
\hline & Control plants & Dusted plants \\
\hline 20 July 1982 & $0 \cdot 19$ & $0 \cdot 17$ \\
21 July 1982 & $0 \cdot 20$ & $0 \cdot 17$ \\
2 August 1982 & $0 \cdot 17$ & $0 \cdot 16$ \\
19 August 1982 & $0 \cdot 18$ & $0 \cdot 16$ \\
23 August 1982 & $0 \cdot 20$ & $0 \cdot 19$ \\
\hline
\end{tabular}

1700, their averages giving the daily mean (Table 1). It was obvious from these periodic measurements that the daily average albedo of polluted plants was $10.5 \%$ lower than that of the control plants.

In 1983-84 we were able to measure continuously and the results were different on clear and completely overcast days. The diurnal variation of

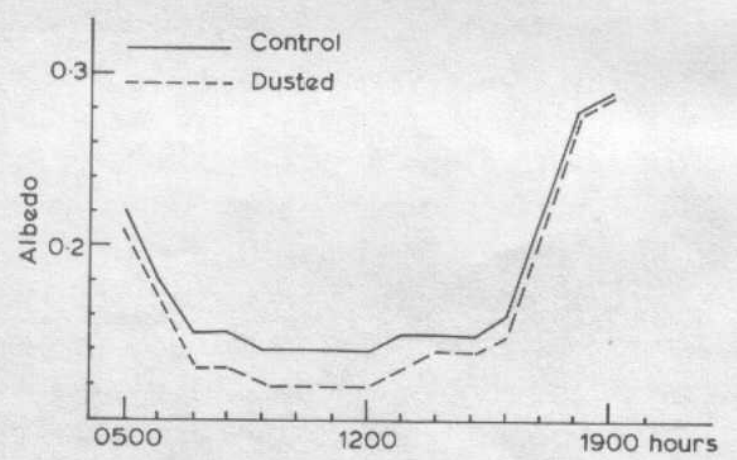

Fig. 2. Diurnal variation of albedo on clear days in July 1984. 


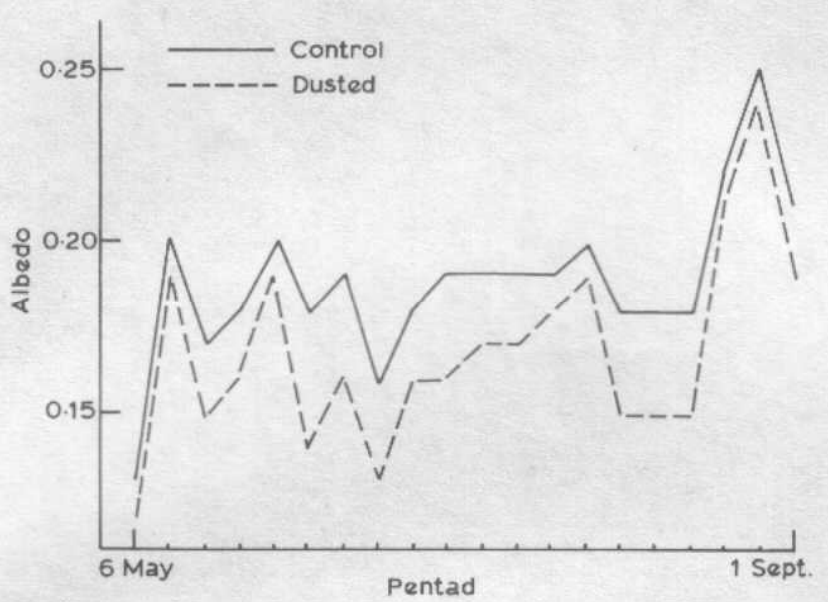

Fig. 3. The seasonal variation of albedo in 1984 .

albedo of polluted and control plants was determined by averaging the hourly values of clear days in July 1984 (Fig. 2). Pollution was found to cause the greatest differences in the morning, and the difference between the early morning and afternoon treatments was reduced. Cement dust is a highly hygroscopic material which becomes saturated at night and at dawn, forming dew. The albedo of water is low compared with other natural surfaces and this may be the reason for the reduced albedo of the polluted plants when measured in the morning. The rising temperature causes the water absorbed by the crust to evaporate and the difference is consequently reduced by the afternoon.

The seasonal variation was obtained from the averages of 5-day periods (data for 1984, Fig. 3). Differences as a result of pollution at the beginning and end of the vegetative period were not so marked. Since reflection is considerably influenced by the size of the assimilatory surface, we measured LAI values every week (Fig. 4). These were as a rule higher for plants polluted with cement, but the shape of the LAI curve was not considerably changed as a result of pollution. The greatest difference caused by pollution was found with maximum LAI values in 1984; the leaf surface of plants from the polluted plots was $6 \%$ higher, and that of the ET pots $17.5 \%$ higher, than the control.

The period when the greatest differences were observed in the curve of polluted albedo values coincided with a marked increase in the LAI values - the leaf surface had probably increased, resulting in a decrease in the reflection of the polluted crop. 


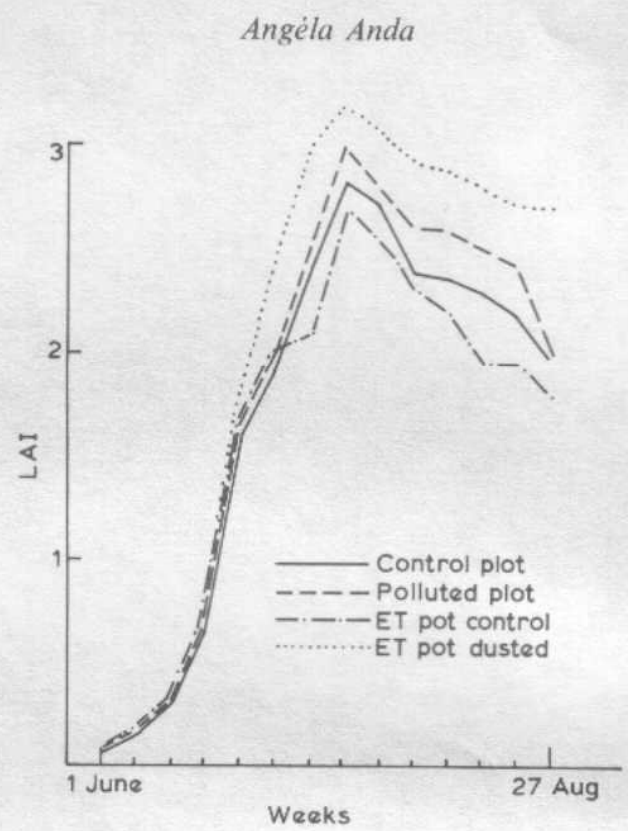

Fig. 4. The seasonal variation of leaf-area index (LAI) in 1984.

There was hardly any difference between the albedo of some of the polluted and control plants for the 5-day period; we established that the number of overcast days during this period increased considerably. On such days, the direction of the deviation is not so evident as it is in sunny weather. There were hours when the albedo of polluted plants was greater or smaller than that of the control and this on the daily average often compensated the difference caused by pollution. With the appearance of clouds, the ratio of the direct and diffuse radiation changes and the absorption of polluted plants is likely to show deviation. The highest deviation was found to occur on clear days.

The albedo of the plants polluted with cement dust decreased by an average of $9.1 \%$ in 1983 and $10.5 \%$ in 1984 , thus revealing that the greater part of the total radiation was kept within the stand. The question, however, still remains whether the surplus intake was used to increase the productivity of the polluted plants.

With this question in mind we determined the amount of dry matter (stalk, leaf, cob) and yields (at $15 \%$ moisture content) per unit area. Dry matter content (at the end of the vegetative period) decreased by an average of $0.24 \mathrm{~kg} \mathrm{~m}^{-2}$ on plots polluted with cement dust, taking into account the average values of the three years. The rate of decrease observed in the vegetative organs was always lower than the deterioration 
TABLE 2

Changes in the Dry Weight $\left(\mathrm{kg} \mathrm{mg}^{-2}\right)$ as a Result of Pollution with Cement Dust, 1982-84

\begin{tabular}{|c|c|c|c|c|}
\hline & \multicolumn{2}{|c|}{ Vegetative organs } & \multicolumn{2}{|c|}{ Generative organs } \\
\hline & $\begin{array}{l}\text { Control } \\
\text { plants }\end{array}$ & $\begin{array}{l}\text { Dusted } \\
\text { plants }\end{array}$ & $\begin{array}{c}\text { Control } \\
\text { plants }\end{array}$ & $\begin{array}{l}\text { Dusted } \\
\text { plants }\end{array}$ \\
\hline 1982 & $0 \cdot 80$ & 0.62 & $0 \cdot 78$ & 0.61 \\
\hline 1983 & $0 \cdot 50$ & $0 \cdot 38$ & $0 \cdot 46$ & $0 \cdot 36$ \\
\hline 1984 & 0.87 & 0.77 & 0.79 & 0.74 \\
\hline
\end{tabular}

in productivity induced by the pollution of generative organs, showing that pollution with cement dust is especially unfavourable for yields and fruit setting (Table 2). Plants polluted with cement dust on the average yielded $16 \cdot 2 \%$ less than the control during the three years.

The annual yield losses are highly weather-dependent, since the appropriate amount of precipitation is very important in compensating for yield loss. For example, during the 1984 vegetative period the amount of precipitation was higher than during the same period in the previous two years, and yield losses were lower.

Since yield losses of maize grown in ET pots were always lower in the polluted plots, it follows that the losses caused by pollution can be reduced by applying additional water.

From these facts it can be seen that the higher rate of radiation intake in a polluted crop-did not affect the final productivity. The rate of radiation increased the temperature of the plants by $1.5-2.5^{\circ} \mathrm{C}$ on a daily

TABLE 3

Differences in the Percentage of Evapotranspiration on Polluted and Control Maize Crop

\begin{tabular}{ccc}
\hline & $\begin{array}{c}\text { Increase in } \\
\text { ctapotranspiration } \\
(\%)\end{array}$ & $\begin{array}{c}\text { Significance } \\
(\%)\end{array}$ \\
\hline 1982 & $+10 \cdot 0$ & \\
1983 & +8.2 & 1 \\
1984 & +6.7 & 5 \\
Mean & $+8 \cdot 3$ & \\
\hline
\end{tabular}


average and, as a consequence, evapotranspiration was more intensive (Table 3). During the three years of the experiment, plants polluted with cement dust used $8.3 \%$ more water. This is especially important in Hungary, since the amount and distribution of precipitation are very irregular during the vegetative period and the water requirement of plants grown on plots subject to pollution - as a result of increased radiation intake and higher plant temperatures - continues to rise, thus increasing the risk of water shortage in plants grown without irrigation in polluted areas.

\section{REFERENCES}

Anderson, P. J. (1914). The effect of dust from cement mills on setting of fruit. Plant World, 17(3), 57-68.

Bohne, H. (1963). Schädlichkeit von Staub aus Zementwerken für Waldbestande. Allg. ForstZtg., 18, 107-11.

Borka, Gy. (1981). Effect of cement kiln dust on the maize plant. Acta agron. Hung., 30, 289-95.

Darley, E. F. (1966). Studies on the effect of cement kiln dust on vegetation. $J$. Air Pollut. Control Ass., 16, 145-50.

Dobreva, C. \& Szlaveva, T. (1974). Zamrszjavaneto sz otpagycson cimentov prah $i$ fotoszintizata na lozata. Gradinarzka i lozarszka nayki Szelszk, Akad. Georgi Dimitrov, Szófia, 91-7.

Eller, B. M. (1977). Road dust induced increase of leaf temperature. Environ. Pollut., 13, 99-107.

Lal, B. \& Ambasht, R. S. (1982). Impact of cement on the mineral and energy concentration of Psidium guayava. Environ. Pollut., Ser. A, 29. $241-9$.

Peirce, G. J. (1910). An effect of cement dust on orange trees. Plant World, 13, 283-8.

Singh, S. N. \& Rao, D. J. (1981). Certain responses of wheat plants to cement dust pollution. Environ. Pollut., Ser. A, 24, 75-81.

Steinhübel, G. (1966). Ucinok prachovej vrstvy na psehrievanie listovej cepele pri priames insolacii. Biológia, Bratisl., 21, 4-12. 